\title{
Teaching Reform of Business Statistics in College and University
}

\author{
Zhenling Liu \\ School of Management, Henan University of Technology, Zhengzhou, 450001, CHINA
}

Received 18 June 2017 • Revised 1 September 2017 • Accepted 19 September 2017

\begin{abstract}
Business Statistics is an important course for teaching administration and business colleges in colleges and universities. In most colleges and universities, traditional "teaching" mode is till used in course teaching of business Statistics; the mode of interfered realization of course teaching goal in a certain extent. In this essay, current status and characteristics of course teaching of Business Statistics were sorted out with guidance of information age background. The study suggested that there were following problems in course teaching of Business Statistics: defects of teaching position, "teaching-learning" was main mode, connection with practical demands was not close enough and etc. In the study, overall reform framework was proposed through content, method and evaluation of course teaching; "Practical Business Statistics" was conducted and used; teaching reform mode with theories and practical teaching was formed which could provide reference for course teaching reform of Business Statistics in colleges and universities.
\end{abstract}

Keywords: business statistics course, direction of reform, teaching mode

\section{INTRODUCTION}

In the $21^{\text {st }}$ century, Business continues developing in China which is becoming a sports power with modernization, informationization and high science technology. As a basement for teaching athletic talents, college and university play an important role in teaching modern athletic talents. Relevant statistics theories will definitely be used in Business exercise, research, software development and other aspects. However, as a newly rising course, Business Statistics has its own problems, like comparatively single teaching form, inaccurate course teaching position and etc. Course teaching of Business Statistics in college and university needs to be explored further.

Business Statistics is a comprehensive course which involves mathematical statistics, Business phenomenon, information technology and other knowledges. It occupied an important position in teaching modern athletic talents. According to Shuxiang ZHAO's "Practical Business Statistics" we can see that Business Statistics mainly consists of Research Design, Descriptive Statistics and Inferential Statistics as shown in Table 1.

It is not difficult to tell from Table 1 that course design contents of Business Statistics are comparatively rich, complicated and boring. For students who are not interested in Math, when teaching form is comparatively simple and practicality of teaching is weak, effect of teaching is comparatively poor. There are three problems as follows:

The first is defect of teaching position in Business Statistics. Because of this, students do not have enough understanding on basic theory of Business Statistics and statistical thinking; it is easy for them to learn but difficult for them to memorize; they make mistakes frequently in practice. At one hand, math properties are emphasized in

(C) Authors. Terms and conditions of Creative Commons Attribution 4.0 International (CC BY 4.0) apply. Correspondence: Zhenling Liu, School of Management, Henan University of Technology, Zhengzhou, 450001, China. 


\section{Contribution of this paper to the literature}

- This article outlines the business statistics teaching difficulties and questions. It gives us how to improve the student's understanding and application in business.

- It is argued that business statistics is an essential tool for students' development in the career. Therefore, the more studying and understanding of statistics, the better they will be.

- Several methods about reforming the business statistics are proposed.

Table 1. Content and classification of Business statistics

\begin{tabular}{|c|c|c|}
\hline \multirow{9}{*}{$\begin{array}{l}\text { Physical } \\
\text { Education } \\
\text { Statistics }\end{array}$} & \multirow{3}{*}{$\begin{array}{l}\text { Research } \\
\text { Design }\end{array}$} & Basic Thought and Method of Statistics \\
\hline & & Design and Principle of Statistics Content \\
\hline & & Design of Investigation and Experiment \\
\hline & \multirow{3}{*}{$\begin{array}{l}\text { Descriptive } \\
\text { Statistics }\end{array}$} & Statistics and Distribution of Frequency \\
\hline & & Sample Statistics and Counting \\
\hline & & Distribution and Description of Normality \\
\hline & \multirow{3}{*}{ Inferential Statistics } & Relevance Analysis \\
\hline & & Regression and Cluster Analysis \\
\hline & & Difference Analysis \\
\hline
\end{tabular}

Reference: Shuxiang ZHAO, Practical Business Statistics [M], Beijing Sports University Press. 2015, September Edition.

course teaching of Business Statistics in college and university; mathematical formulas and inference are involved in Descriptive Statistics, Sample Statistics, Normality Distribution and other sections. As a result, students focus on learning mathematical formulas and abstract theories; valuing degree of students' accepting theories is increased; teaching of Business Statistics method is emphasized; knowledge of Business Statistics theory is not enough. On the other hand, one-sided pursuit of data accomplishment and logicality exists; there is difference between course teaching and students' practical needs; students know but not the why about statistical method.

The second is that teaching form of Business Statistics in college and university is comparatively single. In recent years, although main body position of student has been emphasized in teaching, "teaching-learning" mode is still used as main teaching form of Business Statistics in most colleges and universities; students do not have enough knowledge of Business Statistics practice; formulas and scores are valued highly, practical application of Business Statistics theory is ignored; students' knowledge range is narrow, their abilities of practicing and comprehensively analyzing are weak, they cannot reach demands of Quality Education.

The third is that connection between course teaching and practical demands of Business Statistics in college and university is not close. Current course teaching of Business Statistics in college and university is limited in to textbook; as a result, connection between teaching and application is not close. In practical learning, students do not have a clear understanding about practicability and operability of Business Statistics; it is believed that there is not enough application of Business Statistics learning in life, therefore, students' positivity and proactivity of learning is low.

\section{KEY ELEMENTS REQUIRED IN COURSE TEACHING REFORM OF Business STATISTICS IN COLLEGE AND UNIVERSITY}

Presently, course teaching of still has to face many plights. Especially in today's rapid development of information technology, it is difficult for traditional "teaching-learning" mode to meet demands of social development. Therefore, main body of teaching shall be considered seriously, take demands of students as basis, with the guidance of application of information technology, course teaching mode of Business Statistics can be reformed further, as shown in Figure 1.

As shown in Figure 1, course teaching reform of Business Statistics in college and university must be guided by demands, development of information technology, science and technology. First of all, it shall be guided by practical demands of students. In college and university, relevant courses of Statistics are not required 


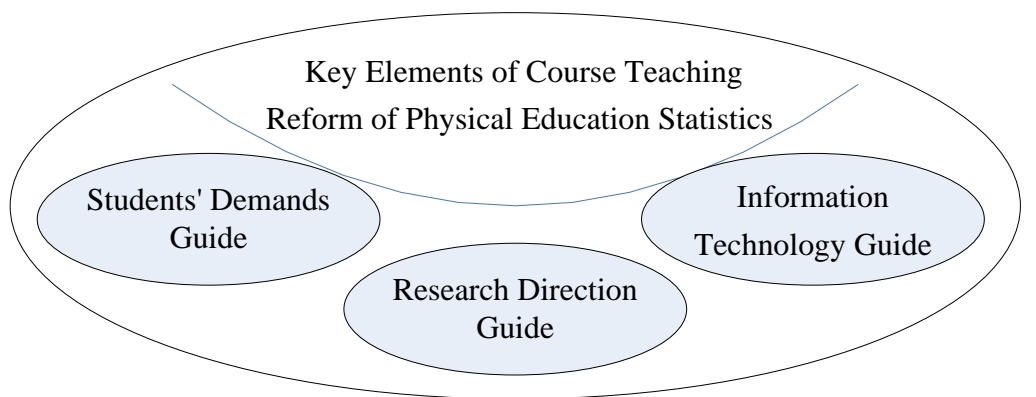

Figure 1. Key of course teaching reform of Business

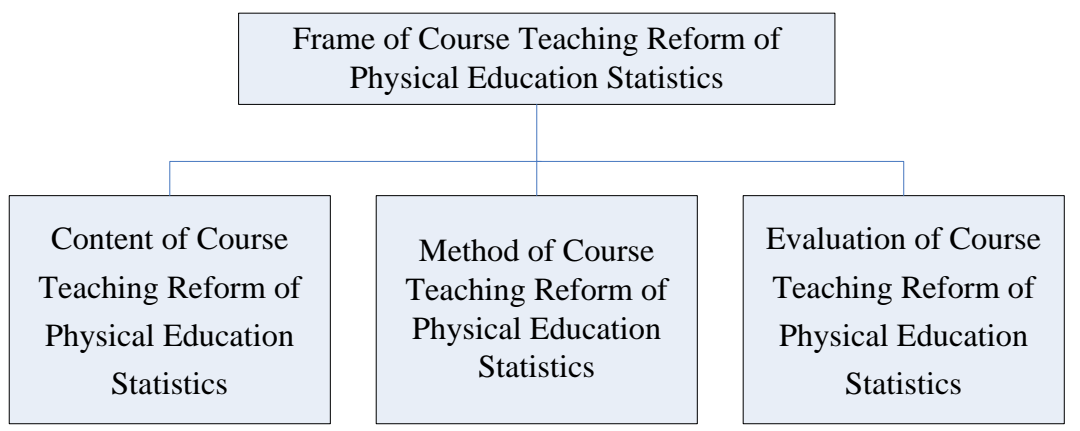

Figure 2. Frame of course teaching reform of Business statistics in college and university

professional courses; especially because most students' math level is not high, so course teaching of Business Statistics must be guided by their practical needs; students' practical receptivity and shall be considered fully, start from practice angle, carry out training of course teaching method of Business Statistics, increase practice experience for students, apply theory in practice and grasp theory through practice; in this way teaching effect can be improved. Secondly, applicability principle is the basis of course teaching method of Business Statistics, teaching work shall be conducted with scientific method. The goal of Business Statistics course is to work for sports and to serve for science and research of Business; therefore, its practicability must be valued, its application in practice needs to be explained more, it shall be connected with scientific research method closely, students will be promoted to realize an organism combination of statistics theory and practice and apply it in practice. Finally, course teaching reform shall be guided by information technology. Complexity of Business accounting is a key to interfere realizing course teaching goal. Most of Business statistics methods are difficult to be spread in Business area; development and application of information technology lower level of difficulty at certain degree; rapid development of statistics software widened developing space for Business Statistics; this is the rule which is the key point in course teaching reform of Business Statistics and must be followed in course teaching.

\section{DESIGN OF COURSE TEACHING REFORM PLAN OF BUSINESS STATISTICS IN COLLEGE AND UNIVERSITY}

\section{Frame of Course Teaching Reform of Business Statistics in College and University}

Course teaching reform of Business Statistics in college and university is a systematic project which involves every aspect of the course, including course teaching content, teaching method, evaluation of teaching and etc. These aspects constitute main content of course teaching; in creation and reform of teaching mode, connection and scientific reasonability of each section shall be valued highly; systematical frame of course teaching shall be formed like shown in Figure 2. 


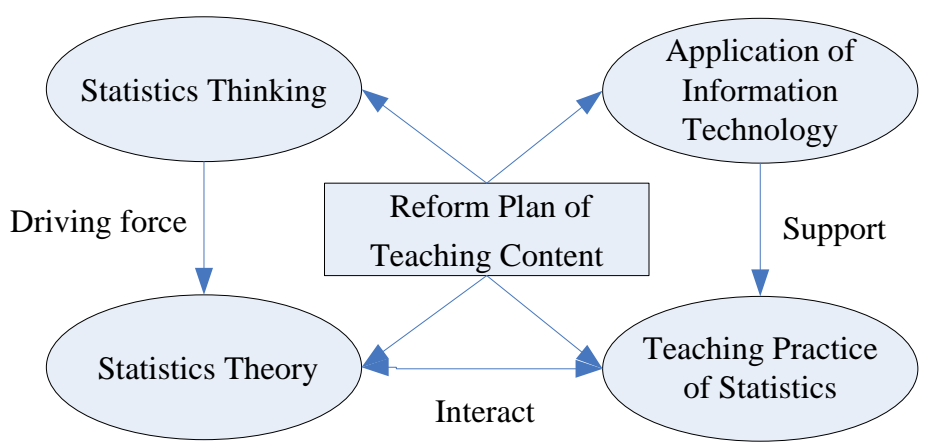

Figure 3. Reforming frame of course teaching content of Business statistics in college and university

\section{Design of Course Teaching Reform Plan of Business Statistics in College and University}

Reform of teaching content is the key of course teaching reform of Business Statistics in college and university. In the reform, developing statistics thinking, building statistics consciousness, informationization of statistics teaching and other works shall be valued; create and reform teaching content in selection and application of teaching content. Firstly, statistics thinking is applied in whole process of course teaching, inferring unity, probability statistics and data variation work shall be carried out. Knowledge required in mastering basic statistics knowledge is comparatively easy, but it is still the basis of understanding statistics thinking; only grasping general resource of statistics theory, can students select correct statistics methods in learning, apply them into practice flexibly, get deeper knowledge of concept and meaning of Business statistics content and play its promoting force (as shown in Figure 3). Secondly, build statistics consciousness for students. Start with angle of why and what in course teaching, lead students to think and solve relevant problems with statistics consciousness. Integrate a large number of practical examples, train students to discover, analyze, plan and solve problems through Business Statistics cases. Thirdly, conduct teaching by scientifically applying information technology, increase practicability of teaching content. SPSS, Eviews, SAS, EXCEL and other system software can be applied widely in Business Statistics, descriptive statistics analysis, discrete regression analysis, correlation analysis and variance analysis can be conducted through them; their application can largely satisfy teaching demands of Business statistics. Developing teaching of Business through informationizaiton software can not only handle calculating complication of statistics theory and weak practicality, but also can it improve students' mastering Business statistics theory through informationization statistics software and enhance vitality of Business Statistic courses. Finally, master method of combining course theory of Business Statistic and practical teaching. Theory is the basis, only practical work can play its function; in practical teaching, apply theory of Business Statistic in research of Business cases, training and planning scientifically and developing Business software, Business statistics is provided with vitality, students' enthusiasm and initiative can be inspired, teaching effect can be improved in practice, supporting function of practical learning and mastering theory can be played (Figure 3). In one word, link of each section shall be highly valued in course teaching of Business Statistics, frame of systematical teaching content reform can be formed, as shown in Figure 3.

\section{Reform Plan Design of Course Teaching Method of Business in College and University}

At present, single course teaching method of Business Statistics is the key of interfering teaching effect, therefore, it is necessary to conduct a reform of teaching method according to practical demands of students in college and university. Firstly, use modern teaching method and create new teaching form. Traditional "teachinglearning" mode play a role of largely depressing on enthusiasm and initiative of learning and killing creativity of students, this is very different from the goal of Quality Education. In order to suit developing demands of informationization Business in background of globalization, it is necessary to master course teaching rules, apply creative teaching methods and promote development of personality. Most Business majors have short attention 


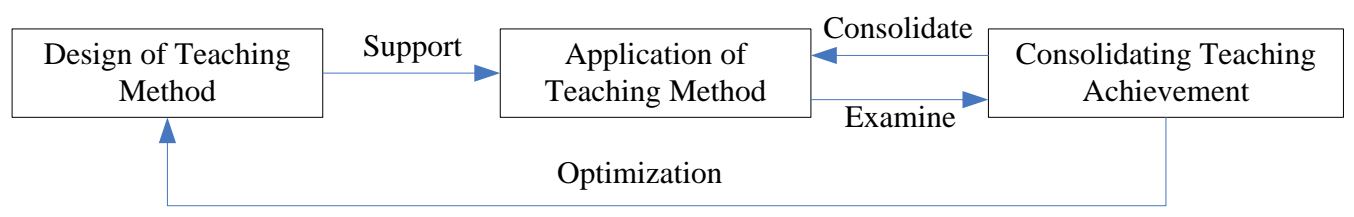

Figure 4. Frame of teaching method reform plan of Business statistics in college and university

span, weak abstract thought and basic theoretical knowledge; therefore, their teachers need to create teaching methods, use instruction method of scene simulation flexibly, personality difference teaching method, layers teaching method and etc., during teaching, they can also apply teaching methods like group discussion, group assignment and tutoring after class; give full play to the initiative of students and role of basic support in the whole system (Figure 4). Secondly, construct unified teaching mode of theory and practice teaching. Theory teaching is focused in traditional teaching mode in which students by rote in order to get high scores; although some students do have good understanding of theoretical knowledge, they cannot apply them in practice, therefore, it is impossible for them to master real quality of the theory in future work and to apply theory into science and research of Business. In time of informationization, practical teaching and computer lab can be added in theory teaching in college and university, students' mastering Business statistics theory can be promoted through displaying and individual tutoring, at the same time, degree of mastering can be deepened. Finally, positive learning after class is key section of consolidating knowledge. It is proved that homework is still an important way to improve students' mastering knowledge. College and university can play a role of consolidating and examining in teaching method reform according to their practical needs (Figure 4), teachers can divide students into several groups, set analyzing assignment and distribute students clearly; students can design questionnaire, investigate, survey, account and analyze data; group competition can be organized, final achievement will be considered as regular performance of students; students will be promoted to master theory of Business Statistics better. In teaching method reform, build a unified frame of teaching method reform plan: design of teaching method -- application of teaching method -consolidating of teaching achievement; applying quality of teaching method can be improved through teaching method design and dynamic optimization and teaching achievement can be consolidated through practical teaching, as shown in Figure 4.

\section{Design of Course Evaluation Reform Plan of Business Statistics in College and University}

As shown in Figure 2, teaching evaluation is also an important component of course teaching of Business Statistics in college and university. Grasp basic demand of mastering course teaching, evaluate function and practicability of science in course teaching. Firstly, evaluation system needs to be developed further in college and university according to demands of course teaching; hierarchy and systematicity of choosing index shall be highly valued in design of evaluation system; examine mastering degree of basic theory and comprehensive knowledge through evaluation index system; evaluate capability of applying theory; form evaluation mechanism and evaluate students' performance subjectively. Secondly, combine practical course teaching in college and university and construct "dual" inspection mode of teaching evaluation -- closed book examination of theory (Figure 5), examine students' mastering degree through examination paper; for practical learning, computer examination or structuration interview examination can be used; combine examining index and basic situation of teaching, design an examination method in which teacher is lead and student representatives are members; conduct competitive examination mode and form unified evaluating mechanism of theoretical and practical knowledge. Finally, in traditional colleges and universities, closed book examination is mainly used. In time of informationization, colleges and universities shall import practical examination which is based students' practice after class. Teacher sends case of solving practical Business problems to each student through system and leads them to solve problems of case with relevant materials. In short, course teaching of Business Statistics evaluation system consists of design 


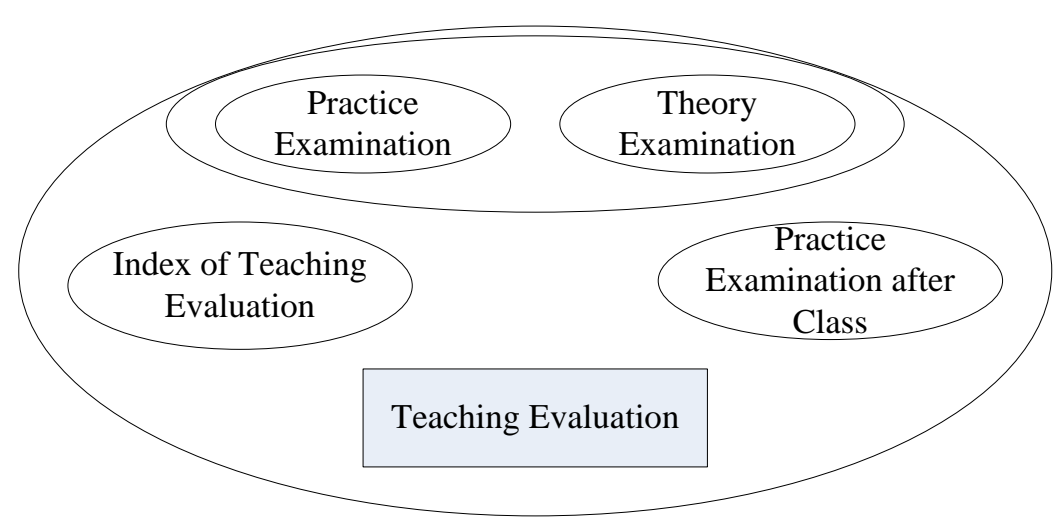

Figure 5. Course teaching evaluation reform plan of Business in college and university

Table 2. Design of course teaching mode of Business statistic in college and university

\begin{tabular}{|c|c|c|}
\hline NO & Key Contents & Teaching Method \\
\hline \multirow[b]{2}{*}{1} & $\begin{array}{l}\text { Basic concepts: Business Statistics, Ensemble, Sample } \\
\text { and etc. }\end{array}$ & Concept explanation is supplement; students explain with samples. \\
\hline & $\begin{array}{l}\text { Obtaining method of science and research data of } \\
\text { Business Statistics: Variant, Data Type, Investigating } \\
\text { Method, Experiment Method and etc. }\end{array}$ & $\begin{array}{l}\text { List questions; students discuss and learn by themselves; sampling } \\
\text { answer questions, teacher explains. }\end{array}$ \\
\hline \multirow{2}{*}{2} & $\begin{array}{l}\text { Data managing method: SPSS Software, creating } \\
\text { data, managing data and making figures and tables. }\end{array}$ & $\begin{array}{l}\text { Teacher explains theoretical knowledge; students practice; students } \\
\text { operate to consolidate; teacher sums up and sublimates. }\end{array}$ \\
\hline & $\begin{array}{l}\text { Descriptive statistics and probability distribution: } \\
\text { Variability, average level, probability function and etc. }\end{array}$ & $\begin{array}{l}\text { Teacher explains concepts; students practice; students operate to } \\
\text { consolidate; teacher sums up and sublimates. }\end{array}$ \\
\hline \multirow[b]{2}{*}{3} & $\begin{array}{l}\text { Normality distribution, sampling deviation, } \\
\text { hypothesis examining, interval estimation, correlation } \\
\text { and regression analysis. }\end{array}$ & $\begin{array}{l}\text { Teacher explains quality; teacher teaches with examples, guide } \\
\text { students to participate; students sums up; teacher evaluates; } \\
\text { consolidate further; students practice; teacher evaluates further; } \\
\text { learn practice after class. }\end{array}$ \\
\hline & $\begin{array}{l}\text { Design of Experiment: research of case and practical } \\
\text { Training after class. }\end{array}$ & $\begin{array}{l}\text { Teacher explains cases of Business Statistic; teachers arrange } \\
\text { students to practice in class; students carry out case researches } \\
\text { according to teachers arrangement; student hand in researching } \\
\text { result of cases; teacher evaluates; students further improve } \\
\text { research method; research have high value for Business science } \\
\text { and research. }\end{array}$ \\
\hline
\end{tabular}

of teaching evaluating index system, practice examination, "dual" theory and practice evaluation mode, as shown in Figure 5.

\section{Specific Practical Method of Course Teaching Reform of Business Statistics in College and University}

From course teaching reform plan design of Business in College and University, we can see that reform mode which focuses on students as main body and combines theory with practice was constructed, "three-in-one" course teaching mode was formed. The study conducted specific practical method from basic concept to practical exploring from angle of Business statistics and according to demands of teaching and development of informationization. Shuxiang SHEN's "Practical Business Statistics" was used as a foundation, management of researching layer in Table 1 and research mentioned above were combined, practical method was built as shown in Table 2. Main body position of students were presented in each section and students' subjectivity was played in positive learning, discussion of learning, operation of learning, live displaying and researching of Businessal topic, specifically show as follows: 


\section{CONCLUSION}

Since the $21^{\text {st }}$ century, information technology develops rapidly. Various and complicated economical problems can be solved with information technology, this provides a more scientific channel to conduct study on social economy. It is a key that how to release Business Statistics as a course with high applicability from pure mathematical teaching and realize its combination with science and research of Business. The study was based on current status of course teaching of Business Statistics, discussed key elements of reform, put forward overall frame of reform and specific plan, provide certain reference to reform. The main points of the study were: put students in position of main body, construct combination mode of theory and practice teaching.

\section{REFERENCES}

Babbie, E. (2002). Basis of Social Researching Method [M] (Z. Qiu, Trans.). China: China Press.

Huang, L. (2010). Rules of Case Teaching of Business Statistics [J]. Sichuan Business Science, (02).

Jia, C. (2009). Investigation and Research of Students' Demands in Course Reform of “Business Statistics" [J]. Beijing Sports University Journal, (06).

Jizhi, C. (Eds.). (2002). Business Statistics [M]. China: People's Sports Publishing House.

Li, J., Qi, G., \& Wang, X. (2009). Observe Business Statistics in College and University Through Misusing Business Statistics [J]. Business Science and Technology, (01).

Sun, C. (2009). Brief Discussion of Problem of "Business Statistics" and Relevant Suggestions [J]. Liaoning Broadcast and TV University Journal, (02).

Sun, W., \& Shi, W. (2009). Application of Business Statistics Method in Scientific Research of Business in China [J]. Scientific Information, (4).

Xie, Y., Liu, C., Yang, K., Yu, M., \& Ma, Y. (2012). Study on Industry Development under Regional Economic Integration -- Take Qinling Shanxi as an Example [J]. Xi'an Business University Journal, (6).

\section{http://www.ejmste.com}

